\title{
Biochemical Characterization by GC-MS of Palm Kernel Oils Produced in Côte d'Ivoire
}

\author{
Ahou Irène Kouadio ${ }^{1}$ \\ ${ }^{1}$ Laboratory of Biotechnologies, Agriculture and Biological Resources, UFR Biosciences, University Felix \\ HOUPHOUËT-BOIGNY, 22 BP 582 Abidjan 22, Côte d'Ivoire
}

Correspondence: Ahou Irène Kouadio, Laboratory of Biotechnologies, Agriculture and Biological Resources, UFR Biosciences, University Felix HOUPHOUËT-BOIGNY, 22 BP 582 Abidjan 22, Côte d'Ivoire. Tel: 00225-070-725-0511 / 00225-014-098-7331. E-mail: irenekouadio@yahoo.fr

Received: March 16, 2021

Accepted: April 28, $2021 \quad$ Online Published: May 14, 2021

doi:10.5539/jfr.v10n3p33

URL: https://doi.org/10.5539/jfr.v10n3p33

\begin{abstract}
The objective of this study was to determine biochemical composition of palm kernel oils produced and consuming in Côte d'Ivoire in order to find out those more suitable for human diet. Our preliminary investigations showed that palm kernel oils consumed in Côte d'Ivoire were those extracted from varieties Dura and Tenera of oil palm (Elaeis guineensis Jacq.) Thus, the types of oils analyzed in this study were oil extracted from the variety Dura (OD) and oil extrated from the variety Tenera (OT). The GC-MS was used to determine the biochemical composition of these oils. The results obtained show that in each oil, seventeen fatty acids were identified by GC-MS. However, among these fatty acids, undecylenic acid was identified only in OD and heptanoic acid was identified only in OT. The two types of oil are rich in saturated fatty acids. However, OD had a relatively higher unsaturated fatty acids content. For the other compounds identified, OT had significantly the highest contents of polyphenols, $\alpha$-tocopherol and sterols with the predominance of $\beta$-sitosterol. These results support that palm kernel oil extracted from the variety Tenera is rich in natural compounds that could be developed as nutraceuticals and phytomedicine. However, some unexpected compounds such as lactones were also identified in the two types of oils. Moreover, it is noted that these lactones were more abundant in oil extracted from the variety Dura (OD).
\end{abstract}

Keywords: palm kernel oil, fatty acids, sterols, polyphenols, $\alpha$-tocopherol, lactones

\section{Introduction}

Malnutrition is the greatest single threat to the world's public health (WHO, 2019). Indeed, malnutrition leads to several diseases (Stratton et al., 2003). However, people more vulnerable are pregnant and lactating women and also young children less than five years (Weber et al., 2015). For these young children, malnutrition can decrease intellectual development and increases also mortality (Barker \& Osmond, 1986). Several metabolic disorders such obesity, high blood pressure and diabetes are often associated to poor dietary intake (Guh et al., 2009; Daniels, 2009). For pregnant women, the threat due to malnutrition is also remarkable. Indeed, Picone et al., (2011) showed that high fat diet during the gestation leads to congenital malformations (Zaloga, 2015). The quality and quantity of oils in diet can thus have an effect on human health as well as animal health. From up to now it is known that vegetable oils are an important source of nutrients which play important role in the diets of people around the world (Kumar et al., 2016). The source of these oils are oleaginous plants. For many years now, oils are usually used for seasoning and to preserve degradation of foods quality (Tchiégang et al., 2004). These vegetable oils are also used in fields such as pharmaceutical, cosmetic and industry (Aubrey \& Huard, 2003). Among the vegetable oils more affordable in Côte d'Ivoire, there is palm kernel oil derived from the kernel which is the residue obtained after palm oil production (Pickard, 2005). This kernel is not only used for oil production. Indeed, the cake of kernel is used for feeding ruminants (Pickard, 2005). It is used also as additive in feed for beef (Ravber et al., 2015).

In Côte d'Ivoire and many African countries, oil extracted from the kernel is used for seasoning the dishes and as food preservative (Yapi \& Kouadio, 2019). Previously, Agboola et al., (2015) have shown that palm kernel oil contained saturated fatty acids as well as monounsaturated and polyunsaturated fatty acids used in African dishes. However, it is not used only for diet. Indeed, it is used in folk medicine for the treatment of dermatoses. 
Moreover, according to Anonyme (2012), the palm kernel oil with its richness in lauric acid which possesses antimicrobial and antiviral properties could be recommended for the diet of people with weak immune system. However, this information should be confirmed by further research. This palm kernel oil could be stored for a long time easily. Indeed, it can be stored at a temperature of $40^{\circ} \mathrm{C}$ for 6 months (Ibiam \& Anosike, 2014).

However, despite this literature relatively abundant found on palm kernel oil, most of the analyses on this oil were carried out using Gas chromatography (GC) which shows most of the time, only the major components (fatty acids).

Thus, in this study, the Gas Chromatography coupled with the Mass Spectrometry (GC-MS) was used to make the screening of the biochemical composition (major and minor components) of palm kernel oils produced and consumed in Côte d'Ivoire in order to identify the varieties of oil palm from which oil extracted could be more suitable for human diet.

\section{Material and Methods}

\subsection{Raw Material}

The biological material used is the palm kernel oil extracted from the kernel of the fruits of varieties of oil palm (Elaeis guineensis Jacq.). Two varieties of oil palm more consumed in Côte d'Ivoire were identified during our preliminary investigations. Indeed, there are variety Dura and variety Tenera.

\subsection{Oil Extraction}

Oil extraction was carried out by using the Soxhlet method described by Yapi and Kouadio (2019). The solvent used was hexane which gives the best oil yield with solid sample according to Mohd-Setapar et al. (2004). The extraction was made at $60{ }^{\circ} \mathrm{C}$.

The total fat content (FA) is given by the following formula:

$\mathrm{FA}($ Total fat content $)=\mathrm{M} 2-\mathrm{M} 1$

Oil yield $=(\mathrm{FA} / \mathrm{M} 0) \mathrm{X} 100$

Oil yield $=[(\mathrm{M} 2-\mathrm{M} 1) / \mathrm{M} 0] \mathrm{X} 100$

Where: M0: mass ( $\mathrm{g}$ ) of the test sample; M1: mass ( $\mathrm{g}$ ) of the empty flask

M2: mass ( $\mathrm{g}$ ) of the flask and the total fat extracted.

Three samples of palm kernel of each variety were analyzed.

\subsection{Determination of Fatty Acids Composition by Gas Chromatography Coupled to Mass Spectrometry (GC/MS)}

The analysis started with the conversion of the oil into fatty acid triméthyl silyl ester. This esterification was conducted following the procedure used by Kloos et al. (2014) and described in the study of Yapi and Kouadio (2020). After the silylation, of the fatty acids by the reagent of N-methyl-N-trimethylsilyltrifluoroacetamide (MSTFA), the analysis was carried out by GC-MS using an apparatus of the PerkinElmer brand, model Clarus 680GC 600C MS. The chromatographic conditions were those described by Yapi and Kouadio (2020).

\subsection{Minor Components Determination}

Several minor components useful for human diet such as sterols, $\alpha$-tocopherol and polyphenols were determined in palm kernel oils.

For sterol determination, saponification of oil was done in order to extract firstly the unsaponifiable. The method of AFNOR NF T60-205 (1984) was used. In order to obtain the trimethylsilyl ether (tms) of sterols which are detectable by gas chromatography coupled to a mass spectrometer (GC-MS), the unsaponifiable fraction was derived by silylation using the method used by Grandgirard and Gordelet (1998). These tms sterols were then identified and quantified by GC-MS using chromatographic conditions used previously by Yapi and Kouadio, (2020).

The quantities of the various sterols of oils studied were calculated as follows:

Sterol $\mathrm{x}(\mathrm{mg} / 100 \mathrm{~g}$ of oil $)=(\mathrm{Px} \mathrm{x} \mathrm{ms} \times \mathrm{100}) / \mathrm{Ps} \mathrm{x} \mathrm{m}$

The content of each single sterol is expressed in milligrams per 100 grams of oil.

With:

Px: peak $x$ area of the sterol,

Ps: peak area of the $5 \alpha$-cholestane, 
ms: mass of added $5 \alpha$-cholestane $(\mathrm{mg})$

$\mathrm{m}$ : mass of the test portion ( $\mathrm{g}$ ).

The percentage of each sterol is given by the relation: \% sterol $\mathrm{x}=(\mathrm{Px} / \mathrm{S}) \mathrm{x} 100$

With Px: area of the peak $x$

S: sum of the areas of all the peaks.

The $\alpha$-tocopherol which is the most active form of vitamin $\mathrm{E}$ was also determined. The analysis was carried out using the standard ISO 14565 (2000) described in previous study by Yapi and Kouadio, (2020). The quantification of the $\alpha$-tocopherol was also done by using a gas chromatograph equipped with a mass spectrometer with the chromatographic conditions described by Yapi and Kouadio (2020). The $\alpha$-tocopherol contents were determined using Emporio brand software.

The total polyphenolic content was also evaluated. This evaluation was done according to the Folin-Ciocalteu method described by Albano and Miguel (2011). The total polyphenols content was determined using a Gallic acid calibration line performed at different concentrations $(20 \mu \mathrm{g} / \mathrm{mL} ; 40 \mu \mathrm{g} / \mathrm{mL} ; 60 \mu \mathrm{g} / \mathrm{mL} ; 80 \mu \mathrm{g} / \mathrm{mL}$ and $100 \mu \mathrm{g} / \mathrm{mL}$ ). The total polyphenol content of the oil samples (T), expressed in milligrams of Gallic acid equivalent per gram of oil (mg EAG / $\mathrm{g}$ of oil) was calculated according to the formula below:

$$
\mathrm{T}=(\mathrm{VxCxd}) / \mathrm{m}
$$

With: V: final volume of the extract $(\mathrm{mL})$,

C: concentration of the extract obtained with the calibration curve $(\mathrm{mg} / \mathrm{mL})$,

d: dilution,

$\mathrm{m}$ : mass of oil in the test sample (g).

\subsection{Statistical Analysis}

Data were analyzed using Statistical Package for Social Sciences (SPSS) version 16. Quantitative data were presented as means \pm SD. The independent sample- ANOVA with post-hoc (LSD) test was used to analyze the mean difference. Probability values $(\mathrm{P})$ of less than 0.05 were regarded as statistically significant.

\section{Results and Discussion}

\subsection{Fat Content of Palm Kernel of Variety Duran and variety Tenera}

The extraction of the fat content did not show a significant difference between the total oil extracted from the variety Dura (OD) and that extracted from the variety Tenera $(\mathrm{OT})(\mathrm{P}>0.05)$. Indeed, the palm kernel oil yields obtained for these two varieties were around 50\% (Table 1).

This value fell in that obtained by Yapi and Kouadio (2019) and also in that indicated by the Codex Alimentarius (2015). It is also noted that the oil yields obtained were similar to that obtained in previous study (Pickard, 2005) which was 50\%, but fell below the range of $75-80 \%$ found by Asuquon (2008). This could be explained by the method of analysis used by this author. However, although no difference was observed between the oil yields of the two types of oil, a difference was noted between the color of oil extracted from the variety Dura (OD) and that extracted from variety Tenera (OT). Indeed, OD was yellow light while OT was orangey yellow (Figure 1).

Table 1. Fat content

\begin{tabular}{llll}
\hline Quality parameters & Samples & & \\
\cline { 2 - 4 } & (OD) & (OT) & $\begin{array}{l}\text { Standards Codex Alimentarius Adopted } \\
\text { in 1999 and amended in 2005-2015 }\end{array}$ \\
\hline Fat content (g) & $4.94 \pm 0.1^{\mathrm{a}}$ & $4.99 \pm 0.1^{\mathrm{a}}$ & - \\
Oil yield (\%) & $49.40 \pm 0.1^{\mathrm{a}}$ & $49.87 \pm 0.1^{\mathrm{a}}$ & 50 \\
\hline
\end{tabular}

Values are means \pm S.D $(n=3)$

Means (means of three samples analyzed) in each row followed by the same letters are similar ( $p>0.05$ ).

Oil extracted from variety Dura (OD)

Oil extracted from variety Tenera (OT) 


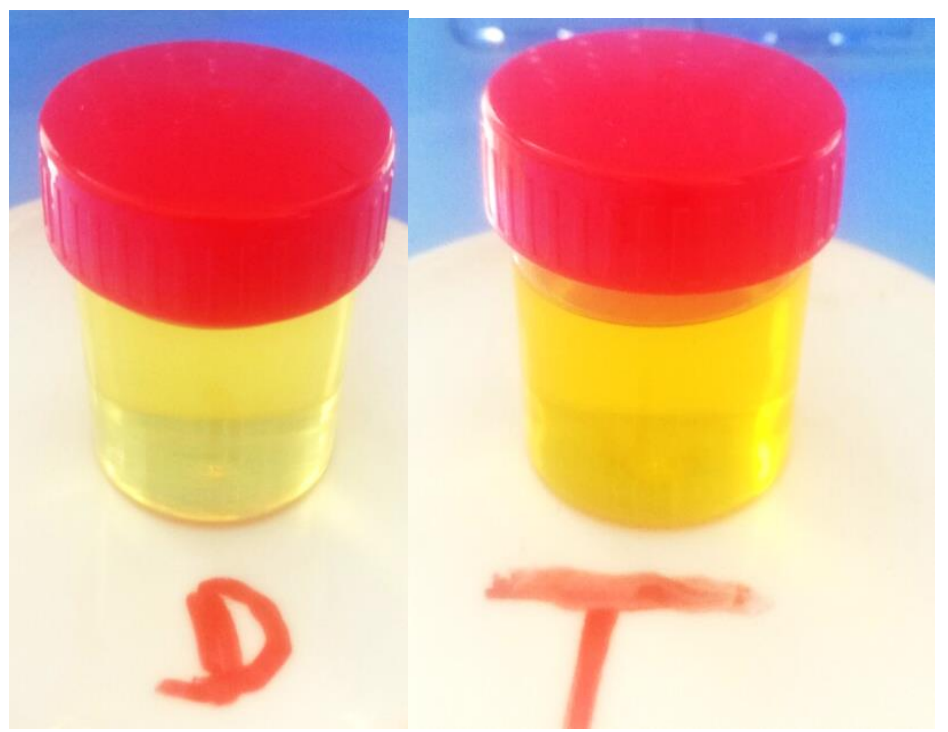

Figure 1. Oils extracted from the variety Dura (OD) with yellow light color and from the variety Tenera (OT) with orangey yellow color

\subsection{Fatty Acids Composition}

The analysis showed 17 types of fatty acids in the two types of oils (OD and OT) (Table 2). The number of fatty acids found in our study was higher than those obtained in previous studies (Mancini et al., 2015; Yapi and Kouadio, 2019). These results show that the fatty acids composition of the palm kernel oil could depend on the type of variety of the oil palm and also on the technic used for the analysis. Indeed, in the present study, the GC-MS was used, while in these previous studies mentioned above, the gas chromatography coupled to flame ionization detection (GC/FID) was used. These oils are rich in saturated fatty acids (Figure 2). This was shown by the ratios of unsaturated fatty acids and saturated fatty acids which fell under that mentioned by the standard of Codex Alimentarius (2015) which is 1 . Indeed, these ratios were 0.250 and 0.220 respectively for OD and OT (Table 2). These results were similar to those obtained by Agboola et al., (2015) and Yapi and Kouadio (2020).

Table 2. Fatty acids composition of palm kernel oils analyzed by gas chromatography coupled to mass spectrometry (GC-MS)

\begin{tabular}{lll}
\hline & OD & OT \\
\hline Fatty acids & Content (\%) & Content (\%) \\
\hline Caproic acid (C6:0), (tms) & $0.03 \pm 0.001^{\mathrm{a}}$ & $0.1 \pm 0.003^{\mathrm{b}}$ \\
Heptanoic acid (C7:0), (tms) & Abs & $0.02 \pm 0.01$ \\
Octanoic acid (C8:0), (tms) & $1.03 \pm 0.11^{\mathrm{a}}$ & $4.53 \pm 0.11^{\mathrm{b}}$ \\
Nonanoic acid (C9:0), (tms) & $0.03 \pm 0.01^{\mathrm{a}}$ & $0.05 \pm 0.01^{\mathrm{a}}$ \\
Decanoic acid (C10:0), (tms) & $1.5 \pm 0.21^{\mathrm{a}}$ & $3.4 \pm 0.18^{\mathrm{a}}$ \\
Undecanoic acid (C11:0), (tms) & $0.02 \pm 0.01^{\mathrm{a}}$ & $0.04 \pm 0.01^{\mathrm{a}}$ \\
Lauric acid (C12:0), (tms) & $50.70 \pm 0.22^{\mathrm{a}}$ & $50.63 \pm 0.19^{\mathrm{a}}$ \\
n-Tridecanoic acid (C13:0), (tms) & $0.04 \pm 0.01^{\mathrm{a}}$ & $0.04 \pm 0.01^{\mathrm{a}}$ \\
Undecylenic acid (C11:1 [cis - 1]), (tms) & $0.01 \pm 0.001^{\mathrm{a}}$ & $\mathrm{Abs}$ \\
Myristic acid (C14:0), (tms) & $18.60 \pm 0.24^{\mathrm{a}}$ & $12.70 \pm 0.17^{\mathrm{b}}$ \\
n-Pentanoic acid (C5:0), (tms) & $0.01 \pm 0.001^{\mathrm{a}}$ & $0.08 \pm 0.004^{\mathrm{b}}$ \\
Palmitic acid (C16:0), (tms) & $6.70 \pm 0.21^{\mathrm{a}}$ & $9.05 \pm 0.21^{\mathrm{b}}$ \\
Heptadecanoic acid (C17:0), (tms) & $0.01 \pm 0.001^{\mathrm{a}}$ & $0.02 \pm 0.001^{\mathrm{a}}$ \\
Trans-9-octadecenoic acid (C18: 1 [trans-9]), (tms) & $7.30 \pm 0.21^{\mathrm{a}}$ & $4.61 \pm 0.18^{\mathrm{b}}$ \\
Oleic acid (C18: 1 [cis-9]), (tms) & $10.40 \pm 0.1^{\mathrm{a}}$ & $10.60 \pm 0.2^{\mathrm{a}}$ \\
Stearic acid (C18:0), (tms) & $1.14 \pm 0.02^{\mathrm{a}}$ & $1.33 \pm 0.11^{\mathrm{a}}$ \\
Linoleic acid (C18: 2 [cis-9,12]), (tms) & $2.60 \pm 0.2^{\mathrm{a}}$ & $2.70 \pm 0.3^{\mathrm{a}}$ \\
Arachidic acid (C20:0), (tms) & $0.04 \pm 0.01^{\mathrm{a}}$ & $0.04 \pm 0.01^{\mathrm{a}}$ \\
\hline
\end{tabular}

Values are means \pm S.D $(n=3)$ 
Means (means of three samples analyzed) in each row followed by different letters are significantly different $(\mathrm{p}<0.05)$.

Oil extracted from variety Dura (OD)

Oil extracted from variety Tenera (OT)

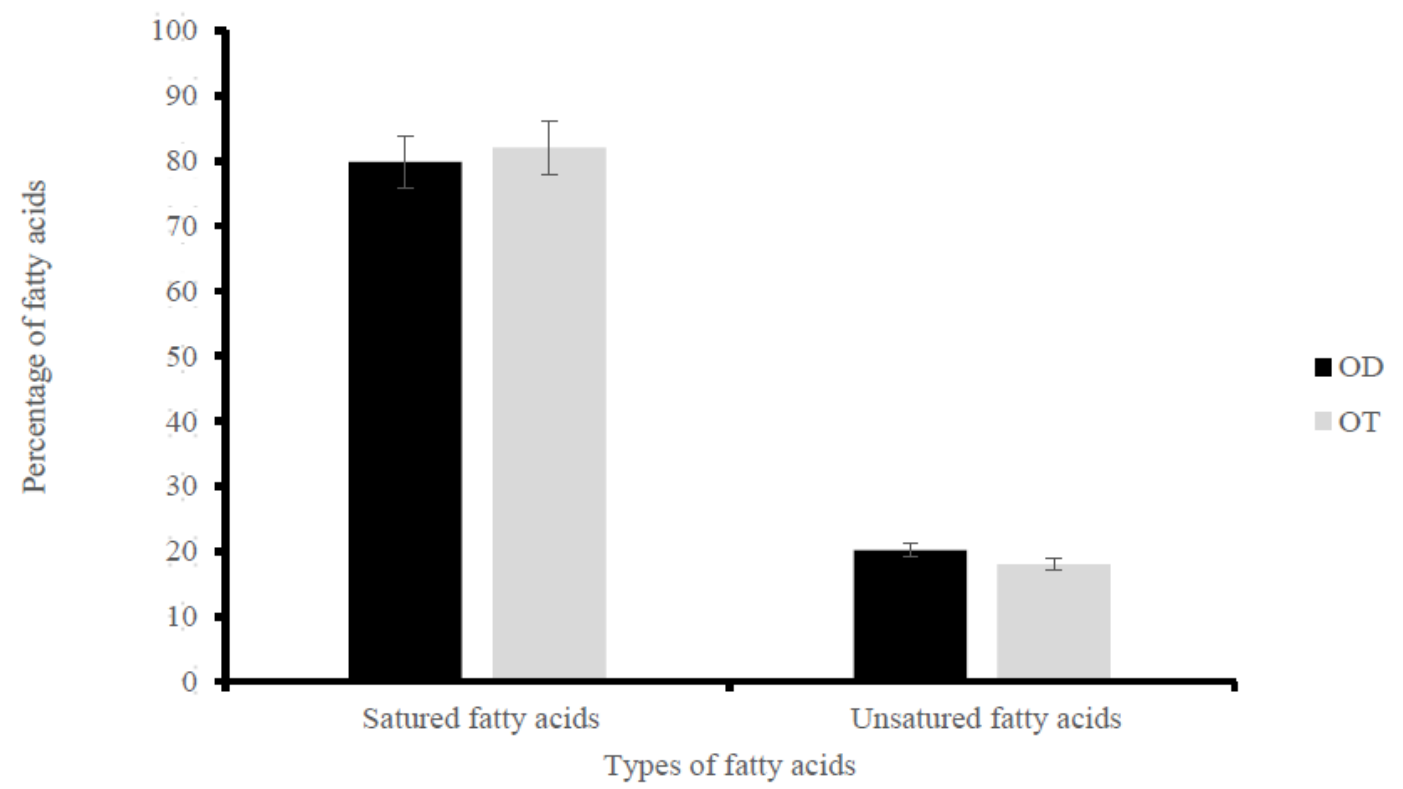

Figure 2. Fatty acids contents of palm kernel oils extracted from varieties Dura (OD) and Tenera (OT)

Regarding the number of fatty acids found in both oils analyzed, OD and OT seem to be similar. However, it is noted that undecylenic acid was identified only in OD, while heptanoic acid was found only in OT (Table 2). These results were similar to those obtained by Yapi and Kouadio (2020). Among these saturated fatty acids, lauric acid was the predominant fatty acid with level of 50.70\% \pm 0.22 and 50.63\% \pm 0.19 respectively for OD and OT. Similar results were obtained by Yapi and Kouadio, (2019) with palm kernel oil. As the benefic effects of lauric acid on health has been shown in previous studies (Orsavova et al., 2015), its presence in oil is an index of quality. Thus, palm kernel oils could be used in many dishes not because they are affordable but also because of their nutritional quality. These oils contained also unsaturated fatty acids with a relative abundance of monounsaturated fatty acids. Indeed, the proportions of monounsaturated fatty acids were $17.64 \% \pm 0.5$ and $15.30 \% \pm 0.4$ respectively for OD and OT. As it is noted, OD is relatively richer in monounsaturated fatty acids than OT. This characteristic is recommended as it makes oil be very stable even in applications such as fried foods (Warner \& Knowlton, 1997). Thus, as it has been shown by Lopes et al., (2016), the consumption of oils contained monounsaturated fatty acids could protect consumers from cardiovascular crisis. Palm kernel oil from variety Dura could thus be used for fried foods.

\subsection{Sterols Composition}

The sterols were also identified in the oils analyzed. The total contents of these sterols were significantly different $(\mathrm{P}<0.05)$. Indeed, the sterols content of OD was $350.0 \pm 1.01 \mathrm{mg} / 100 \mathrm{~g}$ of oil, while that of OT was $4980.0 \pm 1.8 \mathrm{mg} / 100 \mathrm{~g}$ of oil (Table 3). As it noted, OT had the highest total sterols content. The value obtained for this oil is similar to that obtained by Yang et al., (2019) in olive oil. This OT is thus, a good source of sterols. The identification of the sterols fraction revealed the presence of $\beta$-sitosterol, campesterol, and stigmasterol. The predominant sterol in the two types of oil was the $\beta$-sitosterol with proportions of $75.09 \% \pm 1.34$ and $76.29 \% \pm$ 1.8. These amounts of $\beta$-sitosterol were followed by those of campesterol $(13.42 \% \pm 1.06$ and $12.35 \% \pm 0.91)$ and stigmasterol $(11.50 \% \pm 0.8$ and $11.40 \% \pm 0.75)$ respectively for OD and OT (Table 4). However, it is noted that OT was also rich in $\beta$-sitosterol (3799.242 mg / $100 \mathrm{~g}$ of oil) than OD (262.815 mg / $100 \mathrm{~g}$ of oil). This $\beta$-sitosterol has several beneficial effects on health such as the treatment of many types of cancers (AbuMweis et al., 2014). It has also a positive effect on diabetes type II (Yang et al., 2019) and on the improvement of the immune system (Bouic, 1999). That makes this OT very interesting for human diet mainly in this period of the COVID-19 pandemic in which everybody needs a strength immune system to protect himself against this virus 
and other microorganism's infection.

Table 3. Minor components contents of palm kernel oils analyzed

\begin{tabular}{lll}
\cline { 2 - 3 } Components & OD & OT \\
\cline { 2 - 3 } Polyphenols content (mg EAG/g of oil) & $62.30 \pm 1.02^{\mathrm{a}}$ & $94.07 \pm 1.16^{\mathrm{b}}$ \\
$\alpha$-Tocopherol content (mg/100 g of oil) & $44.10 \pm 0.52^{\mathrm{a}}$ & $58.90 \pm 0.76^{\mathrm{b}}$ \\
Sterols content (mg/100 g of oil) & $350 \pm 1.01^{\mathrm{a}}$ & $4980 \pm 1.8^{\mathrm{b}}$ \\
Lactones content (mg/100 g of oil) & $220 \pm 1.1^{\mathrm{a}}$ & $190 \pm 0.91^{\mathrm{b}}$ \\
\hline
\end{tabular}

Values are means \pm S.D $(n=3)$

Means (means of three samples analyzed) in each row followed by different letters are significantly different $(\mathrm{p}<0.05)$.

Oil extracted from variety Dura (OD)

Oil extracted from variety Tenera (OT)

Table 4. Sterols composition of palm kernel oils analyzed

\begin{tabular}{|c|c|c|}
\hline & OD & OT \\
\hline Sterols & $(\%)$ & \\
\hline Campesterol & $13.42 \pm 1,06^{\mathrm{a}}$ & $12.35 \pm 0.91^{\mathrm{a}}$ \\
\hline Stigmasterol & $11.50 \pm 0.8^{\mathrm{a}}$ & $11.40 \pm 0.75^{\mathrm{a}}$ \\
\hline$\beta$-Sitosterol & $75.10 \pm 1.34^{\mathrm{a}}$ & $76.30 \pm 1,8^{\mathrm{a}}$ \\
\hline
\end{tabular}

Values are means \pm S.D $(n=3)$

Means (means of three samples analyzed) in each row followed by different letters are significantly different $(\mathrm{p}<0.05)$.

Oil extracted from variety Dura (OD)

Oil extracted from variety Tenera $(\mathrm{OT})$

\section{$3.4 \alpha$-Tocopherol Content}

The $\alpha$-tocopherol content which is the most active form of vitamin $\mathrm{E}$ was also determined in the oils. The highest content of $\alpha$-tocopherol was found in OT. Indeed, the $\alpha$-tocopherol contents were $44.10 \pm 0.52 \mathrm{mg} / \mathrm{g}$ of oil and $58.90 \pm 0.76 \mathrm{mg} / \mathrm{g}$ of oil respectively for OD and OT (Table 3). The analysis shows that there is a significant difference between the $\alpha$-tocopherol contents of the two types of oil $(\mathrm{P}<0.05)$. As it is known, this compound is important for human being because of it antioxidant property (Kaya, 2009). This compound makes OT great for human diet.

\subsection{Polyphenols Content}

The polyphenols content was also determined in the oils extracted. The linear regression equation of the calibration curve plotted for Gallic acid (Figure 3) was used for this determination. The OT had the highest polyphenols content with a value of $94.07 \pm 1.16 \mathrm{mg}$ EAG / g oil compared to that of the OD which was $62.3 \pm$ $1.02 \mathrm{mg}$ EAG / g oil (Table 3). It is noted a significant difference between the polyphenols content of OD and that of OT $(\mathrm{P}<0.05)$. As these polyphenols are known to be natural antioxidants which are used for the conservation of edible foodstuffs and also in the treatment cancers (Kouamé et al., 2009). Thus, therapeutically, cosmetically and nutritionally, the OT can be considered as interesting oil to recommend for diet. 


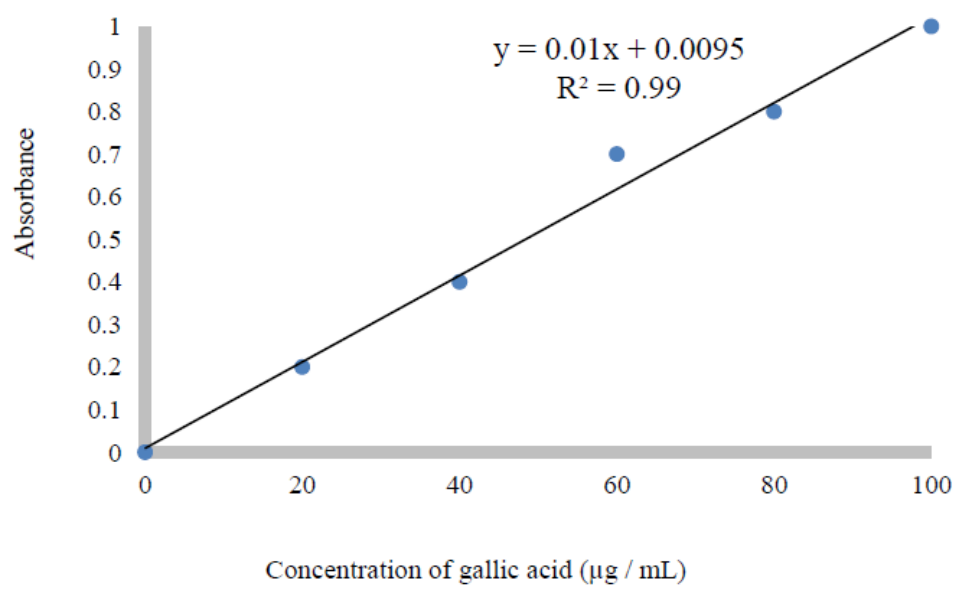

Figure 3. Calibration curve of Gallic acid

\subsection{Lactones Content}

In addition to the minors compounds mentioned above, lactones were found in the two types of oil analyzed.

However, the OD was richer in these lactones than the OT. Indeed, in the OD, the $\gamma$ dodecalactone $(84.65 \% \pm$ $0.95)$ and the $\delta$-dodecalactone $(15.35 \% \pm 0.44)$ were identified, while in the OT, the lactones identified were the $\delta$-decalactone $(52.17 \% \pm 0.68)$ and the $\delta$-dodecalactone $(47.83 \% \pm 0.32)$. As it has been shown in previous studies, the $\gamma$ lactones have the highest flavoring power (Sofiane, 2009). Thus, the richness in $\gamma$-dodecalactone of oil extracted from the variety Dura (OD) makes this oil an excellent source of natural flavoring agents.

Table 5. Sterols composition of palm kernel oils analyzed

\begin{tabular}{lll}
\hline \multicolumn{3}{c}{ Type de lactones $(\%)$} \\
\hline OD & $\gamma$ Dodécalactone & 84.65 \\
& $\delta$-Dodécalactone & 15.35 \\
OT & $\delta$-Décalactone & 52.17 \\
& $\delta$-Dodécalactone & 47.83 \\
\hline
\end{tabular}

Values are means \pm S.D $(n=3)$

Means (means of three samples analyzed) in each row followed by different letters are significantly different $(\mathrm{p}<0.05)$.

Oil extracted from variety Dura (OD)

Oil extracted from variety Tenera (OT)

\section{Conclusions}

This study highlights the variability of the components of oils extracted from varieties of a same oleaginous plant. Indeed, although 17 fatty acids were found in the two types of palm kernel oil derived from varieties Tenera and Dura of oil palm (Elaeis guineensis Jacq.), it is noted that undecylenic acid was found only in OD extracted from the variety Dura while, heptanoic acid was found only in OT extracted from variety Tenera. The OD was relatively richer in unsaturated fatty acids than the OT. However, the predominant fatty acid in both oils was lauric acid. Moreover, the determination of the minor compounds showed that, OT had the highest content of sterols with the $\beta$-sitosterol as predominant sterol. This OT had also the highest contents of $\alpha$-tocopherol and polyphenols. These compounds possess many biological properties such as antioxidant and cholesterol lowering properties. Thus, these results support that palm kernel oil extracted from variety Tenera (OT) with its richness in natural compounds, is more suitable to be developed as nutraceuticals and phytomedicine.

Moreover, OD with its richness in $\gamma$-dodecalactone could be used as a flavor enhancer of dishes.

\section{Acknowledgements}

The authors gratefully acknowledge the laboratory of Biochemical and food sciences and the laboratory of geochemical of PETROCI (Abidjan) for their help during the biochemical analysis. 


\section{Competing interests}

Authors have declared that no competing interests exist.

\section{References}

Abdulkarim, S. M., Long, K., Lai, O. M., Muhammad, S. K. S., \& Ghazali, H. M. (2005). Some physicochemical properties of Moringa oleifera seed oil extracted using solvent and aqueous enzymatic methods. Food Chemistry, 93(2), 253-263. https://doi.org/10.1016/j.foodchem.2004.09.023

AbuMweis, S., Marinangeli, C., \& Frohlich, J. (2014). Implementing phytosterols into medical practice as a cholesterol-lowering strategy: overview of efficacy, effectiveness and safety. Canadian Journal of Cardiology, 30, 1225-32. https://doi.org/10.1016/j.cjca.2014.04.022

AFNOR NF T60-205. (1984). Recueil des normes françaises: corps gras, graines oléagineuses et produits dérivés (3e ed). AFNOR: Paris. pp. 459.

Agboola, J. B., Abubakre, O. K., Mudiare, E., Adeyemi, M. B., \& Hassan, S. B. (2015). Physicochemical characteristics and fatty acids composition of some selected Nigerian vegetable oils for quenching medium. British Journal of Applied Science \& Technology, 8(3), 246-253. https://doi.org/10.9734/BJAST/2015/16177

Albano, S. M., \& Miguel, M. G. (2011). Biological activities of extracts of plants grown in Portugal. Industrial Crops and Products, 33, 338-343. https://doi.org/10.1016/j.indcrop.2010.11.012

Anonyme. (2012). Palm Kernel oil Hudson and knight. Co.za. Hudson and Knight.

Asuquo, J. E. (2008). Studies on the adsorption of some selected metallic soaps onto hematite. Ph.D Dissertation. University of Port Harcourt. L. Palm Kernel Oil Extraction. Chemical Society, 85, $23-28$.

Aubret, J-M., \& Huard, M. (2003). Qualité des huiles et acides gras de palme et des mélanges d'huiles acides, caractérisations chimique et biochimique. Cinquièmes Journées de la Recherche. Avicole; Travail conduit dans le cadre du GIE EURO NUTRITION (France).

Barker, D. J. (1986). Osmond C. Infant mortality, childhood nutrition, and ischaemic heart disease in England and Wales. Lancet, 1, 1077-81. https://doi.org/10.1016/S0140-6736(86)91340-1

Bouic, P. J. D. (1999). The effects of B-sitosterol (BSS) and B-sitosterol glycoside (BSSG) Mixture on selected immune parameters of marathon runners: inhibition of post Marathon immune suppression and inflammation. International Journal of Sports Medicine, 20, 258-262. https://doi.org/10.1055/s-2007-971127

Codex Alimentarius Commission. (2015). Standard for named vegetable oils. “Codex Stan 210 1999”. Adopted in 1999. Amended in 2005, 2011, 2013 and 2015.

Daniels, S. R. (2009). Complications of obesity in children and adolescents. The International Journal of Obesity, 33(1), S60-S65. https://doi.org/10.1038/ijo.2009.20

Grandgirard, A., \& Gordelet, C. (1998). Comparaison de la chromatographie en phase liquide à haute performance et de la chromatographie en phase gazeuse pour l'analyse des oxystérols. Analusis Magazine, 26(3), 55-60. https://doi.org/10.1051/analusis:199826030055

Guh, D. P., Zhang, W., Bansback, N., Amarsi, Z., Birmingham, C. L., \& Anis, A. H. (2009). The incidence of co-related to obesity and overweight: a systematic review and meta-analysis. BioMed Central Public Health, 9, 88. https://doi.org/10.1186/1471-2458-9-88

Ibiam, J. A., \& Anosike, P. O. (2014). Extraction and characterization of palm kernel oil from the kernel of palm tree (Elaeis guineensis). International Journal of Current Research, 6(05), 6696-6698.

ISO, 14565. (2000). Aliments des animaux - Détermination de la teneur en vitamine A et E.

Kaya, N. E. (2009). Alpha-tocopherol: looking beyond an antioxidant. Molecular Vision, 15, 855-860.

Kloos, D., Gay, E., Lingeman, H., Bracher, F., Müller, C. Mayboroda, O. A., Deelder, A. M., Niessen, W. M. A., \& Giera, M. (2014). Comprehensive GC-MS analysis of fatty acids and sterols using sequential one-pot silylation: quantification and isotopologue. Rapid Communication of Mass Spectrometry, 28(13), 1507-1514. https://doi.org/10.1002/rcm.6923

Kohlpaintner, C., Schulte, M., Falbe, J., Lappe, P., \& Weber, J. (2008). Aldehydes, Aliphatic. ULLMANN'S Encyclopedia of Industrial Chemistry. https://doi.org/10.1002/14356007.a01_321.pub2 
Kouamé, J., Gnoula, C., Palé, E. Bassolé, H., Guissou, I. P., Simporé, J., \& Nikiéma, J. B. (2009). Etude des propriétés cytotoxiques et anti-radicalaires d'extraits de feuilles et de galles de Guiera senegalensis. J. F. Gmel Science Technologie., Science santé, 32(1 et 2), 14.

Kumar, A., Aarti Sharma, A., Kailash, C., \& Upadhyayab, K. C. (2016). Vegetable Oil: Nutritional and Industrial Perspective. Current Genomics, 17(3), 230-240. https://doi.org/10.2174/1389202917666160202220107

Lopes, L. L., Peluzio, M. C., \& Hermsdorff, H. H. M. (2016). Monounsaturated fatty acid intake and lipid Metabolism. Jornal Vascular Brasileiro, 15(1), 52-60. https://doi.org/10.1590/1677-5449.008515

Mancini, A., Imperlini, E., Nigro, E., Montagnese, C., Daniele, A., Orrù, S., \& Buono P. (2015). Biological and nutritional properties of palm oil and palmitic acid: Effects on health. Molecules, 20(9), 17339-17361. https://doi.org/10.3390/molecules200917339

Mohd-Setapar, S. H., Lee, N. Y., \& Mohd-Sharif, N. S. (2014). Extraction of rubber (Hevea brasiliensis) seed oil using soxhlet method. Malay. Journal of Fundamental Applied Science, 10(1), 1-6. https://doi.org/10.11113/mjfas.v10n1.61

Orsavova, J., Misurcova, L., Ambrozova, J. V., Vicha, R., \& Mlcek, J. (2015). Fatty acids composition of vegetable oils and its contribution to dietary energy intake and dependence of cardiovascular mortality on dietary intake of fatty acids. International Journal of Molecular Sciences, 16, 12871-12890. https://doi.org/10.3390/ijms160612871

Pickard, M. D. (2005). By-products utilization. In F. Shahidi (Ed.), Bailey's industrial oil products. Edible Oil and Fat Products: Products and Applications (p. 4). Wiley-Interscience. https://doi.org/10.1002/047167849X.bio081

Picone, O., Laigre, P., Fortun-Lamothe, L., Archilla, C., Peynot, N., Ponter, A. A., Bertheloth, V., Cordier, A-G., Duranthon, V., \& Chavatte-Palmer, P. (2011). Hyperlipidic hypercholesterolemic diet in prepubertal rabbits affects gene expression in the embryo, restricts fetal growth and increases offspring susceptibility to obesity. Theriogenology, 75(2), 287-299. https://doi.org/10.1016/j.theriogenology.2010.08.015

Ravber, M., Knez, Ž., \& Škerget, M. (2015). Simultaneous extraction of oil- and watersoluble phase from sunflower seeds with subcritical water. Food Chemistry, 166, 316-323. https://doi.org/10.1016/j.foodchem.2014.06.025

Sofiane, L. (2009). Extraction et caractérisation physicochimique de l'huile de graines de Moringa oleifera. Mémoire en vue de l'obtention du diplôme de Magister en Sciences Agronomiques. Ecole Nationale Supérieure Agronomique El-Harrach Département, Technologie Alimentaire. pp. 115.

Stratton, R., Green, C. J., \& Elia, M. (2003). Disease related malnutrition: an evidence-based approach to treatment. Oxon: Cabi Publishing. https://doi.org/10.1079/9780851996486.0000

Takeda, H., Shibuya, T., Yanagawa, K., Kanoh, H., \& Takasaki, M. (1996). Simultaneous determination of \# tocopherol and \#-tocopherolquinone by High-performance Liquid Chromatography and coulometric detection in the redox mode. Journal of Chromatography A, 722(1-2), 287-294. https://doi.org/10.1016/0021-9673(95)00532-3

Tchiégang, C., Ngo, O. M., Dandjouma, A. A., \& Kapseu, C. (2004). Qualité et stabilité de l'huile de Ricinodendron heudelotii (Bail.) Pierre ex Pax pendant la conservation à température ambiante. Journal of Food Engineering, 62, 69-77. https://doi.org/10.1016/S0260-8774(03)00172-9

Warner, K., \& Knowlton, S. (1997). Frying quality and oxidative stability of high-oleic corn oils Journal of the American Oil Chemists' Society, 74, 1317-1321. https://doi.org/10.1007/s11746-997-0063-7

Weber, M., Ayoubi, J-M., \& Picone, O. (2015). Nutrition de la femme enceinte: conséquences sur la croissance foetale et le développement de maladies à l'âge adulte. Archives de Pédiatrie, 22(1), 116-118. https://doi.org/10.1016/j.arcped.2014.10.017

WHO (Word Health Organization). (2019). Malnutrition is a world health crisis: World Food Day.

Yang, R., Xue, L., Zhang, L., Wang, X., Xin, Q. X., Jun, J. J., \& Peiwu, L. P. (2019). Phytosterol contents of edible oils and their contributions to estimated Phytosterol Intake in the Chinese Diet. Foods, 8(8), 334. https://doi.org/10.3390/foods8080334

Yapi, A. P., \& Kouadio A. I. (2019). Physico-chemical characterization of palm kernel oil Extracted from the seeds of two varieties of oil palm (Elaeis guineensis Jacq.) for possible use in feed or food. European Journal of Nutrition and Food Safety, 9(4), 341-353. https://doi.org/10.9734/ejnfs/2019/v9i430081 
Yapi, A. P., \& Kouadio, A. I. (2020). Antimicrobial and antioxidant activities of Palm Kernel oils extracted from varieties Dura and Tenera of oil Palm (Elaeis guineensis Jacq.) and the Relationship to their chemical composition. Journal of Food Studies, 9(1), 95-117. https://doi.org/10.5296/jfs.v9i1.17071

Zaloga, G. P. (2015). Phytosterols, Lipid Administration, and Liver Disease During Parenteral Nutrition. Journal of Parenteral and Enteral Nutrition, 39, 39S-60S. https://doi.org/10.1177/0148607115595978

\section{Copyrights}

Copyright for this article is retained by the author(s), with first publication rights granted to the journal.

This is an open-access article distributed under the terms and conditions of the Creative Commons Attribution license (http://creativecommons.org/licenses/by/4.0/). 